\title{
Employee Behavior in the Regional Civil Service Agency of East Kutai Regency, Indonesia Social Reality Study on Employee Competency Standards
}

\author{
Sudirman Latif, Agus Sholahuddin, Sri Hartini Jatmikowati
}

University of Merdeka Malang, Indonesia

\begin{abstract}
The purpose of this study is to find out, describe and analyze how the behavior of employees in the Regional Personnel Board of East Kutai Regency and to find out, describe and analyze what things are behind the behavior of employees in the Regional Civil Service Agency of East Kutai Regency. To reveal this reality, qualitative research methods are used where the data obtained is processed by organizing and sorting the data into patterns or categories and descriptions of basic units so that they can be read and interpreted. Based on the facts and phenomena obtained in the field, the results of the research are as follows: First, Order and Order and the discipline of employees at the BKD of East Kutai Regency are an example for the agency, service or other work units are carried out with full awareness and implementation is part of the organizational culture. Second, increasing employee morale and work ethic is carried out by providing motivation as a result of the increasing public demand for public services. Third, in the Civil Service Agency, cooperation is a necessity to realize success in providing public services where with a teamwork system, employees will be helped and feel the benefits compared to working alone. Fourth, at the Employment Agency, the implementation of employee duties and functions can run well and professionally, especially in facing the demands of public services with the provision of education and training on employee reliability in carrying out tasks so that they are carried out with high quality, right time, carefully, and with procedures that are easy to understand and follow by those who need services. Fifth, the improvement of skills, both technical skills and skills to manage self and others owned by ASN in the Regional Personnel Agency of East Kutai Regency is the ability to carry out a certain task, both physically and mentally. Sixth, Efforts to improve the attitude or behavior of employees within the Regional Personnel Agency are carried out in the form of activities whose main purpose is to improve attitudes, attitudes and behavior that can be said to be very supportive in the duties of an employee in carrying out his work. Seventh, Employees of the Regional Personnel Agency of East Kutai Regency are given motivation and enthusiasm at all times so that they are disciplined in completing their duties and functions as stated in the description of duties and functions of positions and responsibilities. The factors behind the behavior of employees of the Regional Personnel Agency of East Kutai Regency include the existence of an employee recruitment process carried out through direct appointments, through computer answer sheets, and thirdly, the computer assisted test (CAT) system with methods and questions that have undergone changes, is carried out seriously. because it will have an impact in the future in having an impact on the institution occupied by the employee. The education level of employees of the East Kutai Regional Personnel Agency influences the mindset of employees which can be improved through the implementation of formal and non-formal education in the form of training as a means to improve work behavior and employee performance. This knowledge of an employee is part of supporting employee competence in completing job duties well but in practice there are still many that are not in accordance with the existing position. Employees at the East Kutai Regional Personnel Agency will be motivated to work diligently if salaries are paid on time, especially if their salaries are increased in times of need and prices are increasing and the impact on employee income is an increase in employee behavior or competence. The employee's lifestyle is related to employee behavior so that employees must be able to adjust their daily life patterns with the income earned and not take credit from banks beyond the employee's ability limit, resulting in employees no longer focusing on work which is their duty and responsibility. The environmental situation of the BKD Office in East Kutai Regency has an influence in shaping the work behavior of BKD employees, although they still borrow the Bappeda building, making the work atmosphere not optimal, but a good working atmosphere is created and the relationship between employees is also good, also supported by adequate work facilities.
\end{abstract}

Keywords: Employee Behavior, Competency Standards. 


\section{INTRODUCTION}

Civil Servants as government apparatus in carrying out the main tasks of government and development are often faced with the complexity of a fairly dense workload, where they are required to be able to carry it out optimally. For this reason, it is necessary to have high work performance as a very basic factor that must be owned by employees. To grow this work performance, employees should be seen as a human resource asset that requires good, efficient and effective management. The policy of managing employees as human resources is an effort to develop various potentials in the employee, so that in the end one of the results will be obtained in the form of increasing work performance.

Performance is a combination of one's desire with energy that is directed to be able to achieve the intended goal. Work motivation is the cause of an action. Performance can be in the form of personal satisfaction, feeling of being able to achieve something, getting rewards (award/reward) or avoiding punishment (sanctions or punishment). Not everyone is motivated by the same thing, with the passage of time motivation can change. The problem of reduced performance in a person can be caused by economic pressure from the family, personality conflicts, lack of understanding that an attitude can have a certain impact on others.

Strong performance is believed to be the mainstay of performance improvement, in this case performance development is a very important internal focus, because performance is the essence of philosophy to achieve success, namely by creating values that provide general direction and behavioral instructions for all organizational components from superiors. to the lowest level in the organization.

To deal with social changes that are increasingly rapid and diverse, organizations are required to develop management capabilities to anticipate events and changes that may occur in a short or long period of time, as well as strategies and methods that need to be designed to deal with or overcome if these things become a problem. Included in the development of this organizational culture is a strategy to provide services to users of the organization's services. The influence of organizational culture cannot be separated from the existence of the organization as a human being, which, like other humans, encourages the growth of certain forms of culture. Each organization has its own language about history (its myths) and people who are examples of good and bad behavior (legends). both historical and contemporary. In various ways, the various elements of this culture, state to members of the organization what is allowed and what is not according to Hall (1998: 47) [1].

Improving the human resources of the apparatus through an increase in attitude or behavior competence in general is what makes Civil Servants have to improve their work behavior. Work behavior is part of work performance which discusses every behavior, attitude, or action taken by Civil Servants (PNS) in accordance with the Regulation of the Head of the State Civil Service Agency (Perka BKN) no. 1 of 2013. Aspects assessed in work behavior are service orientation, integrity, commitment, discipline, cooperation, and leadership. Because the aspect being assessed still provides a global description, the employee appraisal process still tends to calculate it for themselves according to the opinion of the appraising individual.

The quality of work of government officials or better known as Civil Servants (PNS), is often called inadequate or lacking quality, especially in providing services to the community. Civil servants are considered not to meet the operational standards of services that have been determined by the government and the community due to several things, including the slowness of services that are directly related to the community, the work done is not well coordinated, lack of respect for working hours, discipline that is still up and down and working time indicated that the quality of the government apparatus needed to be improved immediately.Work behavior that covers every behavior, attitude or action taken by a civil servant. The elements of work behavior include service orientation, integrity, commitment, discipline and cooperation as well as leadership. With this work behavior, it is hoped that every civil servant will show his best ability in contributing to organizational goals. This is in accordance with what Hasibuan (2000) said that aspects of work performance include things such as loyalty or loyalty, work results, honesty, discipline, creativity, cooperation in a team, leadership, personality, initiative or original thinking in analyzing, assess, create etc. Next is the ability to unite every existing element and be responsible for every task that is done [2].

Civil servants must have competence due to the duties, principal, functions, authorities and responsibilities that must be carried out, namely providing public services, implementing good governance, in an effort to keep pace with changes in the rapidly changing strategic environment, be it the organization's internal environment, as well as the organization's external environment; the development of science, technology and the ongoing era of globalization that cannot be denied and prevented;and the implementation of regional autonomy.

\section{LITERATURE REVIEW}

\subsection{Theory Social Behavior}

Social behavior is an atmosphere of interdependence which is a must to ensure human existence (Ibrahim, 2001) [3]. As evidence that humans in fulfilling the needs of life as individuals cannot do it alone but need help from others. There is a bond of 
interdependence between one person and another. This means that human survival takes place in an atmosphere of mutual support in togetherness. For this reason, humans are required to be able to work together, respect each other, do not interfere with the rights of others, be tolerant in the lives of employees.

\subsection{Social Exchange Theory}

Maninowski defines exchange as a relationship of exchange (principle of reciprocity) based on non-material rewards that are shown to bind relationships with one another and maintain the order of a society (study of primitive societies in Trobiand) (Malinowski, 1997) [4] . Clark explained that social exchanges can be rigid or loose depending on the closeness of the relationship between them. If the relationship between two people who are still strangers (acquaintances, business partners) the relationship takes place based on a rigid/strict exchange (what is given must be balanced with what is received). On the other hand, in intimate relationships (family members, close friends), people are more responsive to the needs of others and less concerned about the balance between capital (inputs) and gains (outcomes) (Mills, 1976) [5].

\subsection{Management Human Resources}

Hasibuan (1995:4) explains that resource is the capacity to take advantage of opportunities or raise oneself from adversity [6]. Resources can be in the form of objects or circumstances that have the capacity to enable doing something, which in the above definition of something is to take advantage of available opportunities or free oneself from difficulties.

Challenge the current manager or leader is responding to external changes so that the company's internal environmental factors become strong and competitive. Dessler (2000:59) defines Strategic Human Resource Management as follows: "Strategic Human Resource Management is the linking of Human Resource Management with strategic roles and objectives in order to improve business performance and develop organizational cultures and foster innovation and flexibility" [7 ].

\subsection{Competence}

Competence is a description of the qualitative nature of a person's behavior. According to Lefrancois (1995: 5) competence is the capacity to do something, resulting from the learning process [8]. During the learning process, the stimulus will combine with the contents of the memory and cause a change in the capacity to do something. If a successful individual learns how to do a complex job before, then in that individual there must have been a change in competence. Changes in competence will not appear if then there is no interest or opportunity to do so. Thus it can be interpreted that competence is a long-lasting one that causes individuals to be able to perform certain performances.

\subsection{Theory Social Interaction}

Berger and Luckman (1991) say institutions are created and maintained or changed through human action and interaction [9]. Although social institutions look objectively real, in reality they are all built on subjective definitions through the process of interaction. New objectivity can occur through repeated affirmations given by others who have the same subjective definition. At the highest level of generality, humans create the world in a universal symbolic sense, namely a comprehensive view of life, which legitimizes and regulates social forms and gives meaning to various fields of life. the construction process,

\subsection{Theory Social Change}

In the group of classical social change theories, four views of famous figures have been discussed, namely August Gomte, Karl Marx, Emile Durkheim, and Max Weber). August Gomte stated that social change takes place in an evolutionary manner through a stage of change in the realm of human thought, which Gomte calls Intellectual Evolution. The stages of thinking include three stages, starting from the Primitive Theological stage; transitional metaphysical stage, and finally the positive rational stage. Each change in the stage of human thought affects other elements of life, and as a whole also encourages social change.

\subsection{Phenomenological Theory}

The thoughts of Berger and Luckmann were of course also influenced by the thoughts of many other scientists, either directly becoming their teachers or simply influenced by the thoughts of their predecessors. If traced, we can identify that Berger 
was directly influenced by his teacher who is also a phenomologist, Alfred Schutz. Schutz himself was a student of Edmund Husserl, the founder of phenomenology in Germany. On this basis, Berger's thinking is said to be influenced by phenomenological thinking.

It cannot be denied that the thought initiated by Berger and Luckmann is a derivation of a phenomenological perspective that has gained fertile ground both in the fields of philosophy and social thought. The flow of phenomenology was developed by Kant and passed on by Hegel, Weber, Huserl, new Schutz to Berger and Luckmann (Basrowi, 2002:204) [10]. The term sociology of knowledge which is attached to their thinking is actually not a new thing, previously the pioneers towards the sociology of knowledge have been introduced by Max Scheler and Karl Manhein.

\subsection{Theory Symbolic Interactionism}

The perspective of symbolic interactionism seeks to understand human behavior from the point of view of the subject under study. This theory emphasizes that human behavior is seen as a process that involves individuals to shape their behavior by considering the expectations of the people who interact with them (Backer in Mulyana, 2006:230) [11]. The definitions they give to other people, situations, objects, and even themselves determine their behavior.

\subsection{Structural Functionalist Theory}

According to the structural-functional perspective (Durkheim; Parsons), society is basically an organic whole that has its own reality and has a set of needs or certain functions that must be fulfilled by the parts that are its members in order to remain normal and become lasting. The consequence is that if the needs are not met, there can be social imbalance which is seen as 'Pathological'. Therefore, functionalism is: (1) social reality is considered as a system, (2) system processes can only be understood in the reciprocal relationship between parts, (3) a system is bound by efforts to maintain integrity (Soekanto, 1988:21). [12]. Thus, it can be said that the basic structural functionalism theory wants people to live in a peaceful and stable atmosphere bound by the values and norms of society.

\section{RESEARCH METHOD}

\subsection{Research Focus}

The focus of research in this study is on the problem of Behavioral competence (attitude), supporting and inhibiting factors in improving performance. With the formulation of a good research focus, the author will avoid collecting irrelevant data and not being trapped in a general and broad field.

The focus in this research are:

\section{Employee behavior is seen from:}
a. Order and discipline
b. Work ethic/work ethic
c. Cooperation
d. Professionalism
e. Skills
f. Attitude
g. Responsibility

2. The factors behind the behavior of employees:
a. The process of recruitment or selection of employee recruitment
b. Education.
c. Knowledge
d. Income
e. Lifestyle
f. Environment 


\subsection{Data Analysis Technique}

The main principle in data analysis is how to make the data or information that has been collected presented in the form of a description and at the same time provide meaning or interpretation so that the information has scientific or theoretical significance. Qualitative data analysis according to Bogdan and Biklen (Miles and Hubberman, 2014:14) is an effort made by working with data, organizing data, sorting it into manageable units, synthesizing it, looking for and finding patterns, finding what is important and what is learned. and decide what to tell others [13]. Meanwhile, according to Seiddel, qualitative data analysis goes through several processes, namely taking notes which produce field notes with them being coded so that the data sources can still be traced, collected, Data were analyzed using several steps according to the theory of Miles, Huberman and Saldana (2014), namely analyzing data with three steps: data condensation (data condensation), presenting data (data display), and drawing conclusions or verification (conclusion drawing and verification). Data condensation refers to the process of selecting, focusing, simplifying, abstracting, and transforming data [13].

\section{ANALYSIS OF RESEARCH RESULTS}

\subsection{Behavior of the Regional Personnel Agency of East Kutai Regency}

At the Regional Personnel Agency of East Kutai Regency, employee behavior is a very important part in the organizational life of the Regional Personnel Agency of East Kutai Regency. Work behavior is the actions and attitudes shown by employees who work. According to Bond and Fred Meyer (Wathon, 2005) work behavior is the ability to work and behaviors where it is very important in every job or work situation [14]. Meanwhile, according to Robbins (2002:35-39) work behavior is how people in the work environment can actualize themselves through attitudes at work [15]. Robbins's opinion emphasizes the attitude taken by workers to determine what they will do in their workplace environment.

\subsubsection{Order and Discipline}

The phenomenon that shows that there are problems of order and discipline for employees, especially in the East Kutai Regency Personnel Agency, becomes homework that must be addressed continuously because it is the Regional Personnel Agency employees who should be the role model for other agencies, offices or work units. The above shows that civil servants as elements of the State Apparatus in carrying out the wheels of government are required to carry out their duties, principals and functions, and uphold the dignity and image of staffing for the sake of the nation and state. In order to become a reliable, professional, and moral employee, a civil servant must be able to improve the mental attitude of work discipline and be motivated to increase performance effectiveness.

The system for fostering order and discipline for employees within the Regional Personnel Agency of East Kutai Regency which is instilled by employees in the form of awareness about order and discipline in each employee's work environment shows that the organization has carried out early supervision and guidance in the work environment regarding order and discipline.

The success of an organization in achieving a goal is not only determined by the quality of professionalism but also determined by the discipline of its members. For government officials, the discipline includes elements of obedience, loyalty, sincerity in carrying out their duties and the ability to sacrifice, in the sense of sacrificing personal and group interests for the interests of the state and society.

The behavior of order and discipline of employees as part of the organizational culture is also in line with the opinion of Alvin (2004) which states that the cultivation of disciplinary values can develop if it is supported by a conducive environmental situation, namely a situation characterized by consistent treatment from the organization and the work environment or the leadership of the organization. . In addition, a highly disciplined work environment and leadership are effective role models for the development of self-discipline. Order and self-discipline have a very big role in achieving organizational goals. Through selfdiscipline an employee in addition to respecting himself also respects others.

Based on the discussion above, several findings can be obtained:

Finding 1 : The order and discipline of employees at the BKD of East Kutai Regency is an example for other agencies, offices or work units

Finding 2 : The order and discipline of employees at the Regency BKD has become an obligation for employees and is carried out with full awareness.

Finding 3 : The order and discipline of employees at the Regency BKD is part of the organizational culture supported by a conducive environmental situation 
From the findings regarding the Behavior of the Regional Personnel Agency of East Kutai Regency seen from Order and discipline are obtained:

Proposition 1 : Order and discipline of employees at BKD East Kutai Regency is an example for other agencies, offices or work units carried out with full awareness and implementation is part of the organizational culture

\subsubsection{Work spirit / work ethic}

The success of the organization in the work process to achieve the goals that have been set is strongly influenced by the morale of the employees themselves. As we know that morale is a feeling related to the employee himself in carrying out his duties diligently and always being responsible for what he does. If employees have a good work spirit, the goals of the organization will be easier to realize. Vice versa, if the employee morale is bad, then the goals of the organization will be difficult to realize. When we discuss the organization of government agencies, of course the workforce referred to here is civil servants.

Creating employee morale needs to be carried out by the East Kutai Regency Personnel Agency organization so that employees can carry out their work effectively and efficiently. A leader must be able to create and maintain good relationships with employees, create a comfortable work environment, and always try to improve working conditions, so that a comfortable atmosphere can support the development of employee morale.

In addition to enthusiasm for work, one of the progress of a company isOrganizations can also be influenced by several factors owned by employees such as a good work ethic. Where if the employee has a good work ethic then the organization will automatically be given benefits and vice versa if the employee has a low work ethic then the service performance is not as expected. To be able to answer this challenge requires dedication, hard work and honesty at work. Work ethic is a basic attitude in an employee who builds work behavior based on mental awareness, belief, accompanied by full commitment to the work activities he does as a whole.

The phenomenon of observation in the field shows that the Regional Civil Service Agency in increasing the morale of its employees is carried out by always motivating its employees to always be enthusiastic in carrying out a job. Giving motivation is carried out every day before carrying out activities, motivation so that employees remain enthusiastic at work. This is important to do, because advanced employees are employees who are able to have the ability to appreciate the order in the work culture that exists within their scope of work.

Another phenomenon found in the Regional Personnel Agency of East Kutai Regency regarding the spirit and work ethic of employees shows that due to the increasing demands of the community for public services, employees are required to further improve their work spirit and work ethic. This is carried out at the Regional Personnel Agency of East Kutai Regency where at any time during the briefing, both during morning apples and at technical meetings, there is always an emphasis that work spirit or work ethic is a basic moral value that will provide motivation and mental spiritual encouragement for students. employees to be able to complete their duties and functions, which in the end the employee will show high achievement in carrying out his profession.

Based on the discussion above, several findings can be obtained:

Finding 4 : The Regional Civil Service Agency in improving the morale and work ethic of its employees is carried out by always motivating its employees

Finding 5 : As a result of the increasing public demand for public services, employees are required to further improve their morale and work ethic

Finding 6 : The Regional Personnel Agency of East Kutai Regency shows that work ethic is a basic attitude in an employee who builds work behavior based on mental awareness, confidence accompanied by full commitment to the work activities he does as a whole.

From the findings regarding the Behavior of the Regional Personnel Agency of East Kutai Regency seen from Enthusiasm and Work Ethic obtained:

Proposition 2 : Increasing employee morale and work ethic is carried out by providing motivation As a result of the increasing public demand for public services 


\subsubsection{Cooperation}

The phenomenon of cooperation between Regional Personnel Agency employees is found that in public service agencies, cooperation is a necessity to realize success. There must always be coordination between superiors and subordinates. Every time there is a decision, it is always coordinated with each other, so that good communication is established. However, it must be admitted that there are employees who work alone, making their own decisions. This is what we are trying to avoid. To prevent unilateral decision making. Because again, as a public service agency, its employees work in team work.

The above is in line with Chang (2001:3) who says the team is a collection of people who when joined in a team will have certain needs which include; effective communication, active listening, resolve conflicts that arise, and maintain motivation among team members. While the work team is a group in which the individual produces a level of performance that is greater than the individual's input (Robins, 2006:358) [16]. In general, work teams can also be defined as formal groups consisting of separate individuals and are responsible for achieving a goal (Robins, 2006:356) [16]. The purpose of forming a team is so that the work carried out can be completed effectively and efficiently compared to if the work is done individually.

On badan public services such as BKD cooperation is a necessity to realize success. This shows that teamwork is a form of social interaction by a group of people with different abilities, talents, experiences, and backgrounds, who gather together to achieve one goal. Despite their differences, a common goal is the link that unites them as a team. Teamwork is shown by the presence of several individuals who work together who have the same vision and mission to achieve the targets to be achieved in the organization (Pandelaki, 2018) [17].

Teamwork is a necessity in realizing work success. Teamwork will be a driving force that has energy and synergy for individuals who are members of a team. Without good cooperation, there will be no bright ideas. As stated by Bachtiar (2008:58) that "Cooperation is the synergy of the strengths of several people in achieving a desired goal. Cooperation will unite the power of ideas that will lead to success" [18].

In general, the observations show that Teamworkhas an important role for the organization and every individual in it. Cooperation can increase morale, productivity, social relations, communication and efficiency at work. Collaboration is proven to be beneficial for organizational success. In addition to benefiting the organization, cooperation also has an important role for us. When able to work with a team, it allows us to become more creative and more successful people.

Based on the discussion above, several findings can be obtained:

Finding 7 : Employee cooperation in the Regional Civil Service Agency is a necessity to realize success in providing public services.

Finding 8 : At the Regional Personnel Agency, cooperation is well established by knowing the purpose of work, preparing work profiles, always giving positive messages to fellow co-workers and respecting every opinion and also the habits of co-workers.

Finding 9 : At the Regional Civil Service Agency, it is difficult for employees to work alone, so that the teamwork system will be helped and feel the benefits compared to working alone

From the findings regarding the Behavior of the Regional Personnel Agency of East Kutai Regency seen from Cooperation is obtained:

Proposition 3 : At the Civil Service Agency, cooperation is a necessity to realize success in providing public services where with a teamwork system employees will be helped and feel the benefits compared to working alone.

\subsubsection{Professionalism}

Civil servants as public servants must be professional in serving the community as an effort to achieve a 'feel good service' both for the community as recipients and for civil servants as service providers themselves. To provide such services, civil servants must work in accordance with applicable laws and be supported by adequate capabilities and expertise. Therefore, civil servants must understand the relevant regulations and receive adequate and appropriate training and education. To maintain the professionalism of civil servants in providing public services requires commitment from all employees as well as periodic monitoring and evaluation.

Employee professionalism as the attitude and behavior of employees who are capable and reliable and knowledgeable in their fields are expected to be able to carry out their work in serving the community at large in accordance with the field they are involved in. Professional employees in question are certainly influenced by the initial recruitment or acceptance process since 
prospective employees are tested for their abilities and attitudes to become employees, incentives, education and training as well as a well-planned career coaching system.

The phenomenon in the field shows that at Badan Regional Employment of East Kutai Regency in the administration of government in the context of achieving good governance, of course it is necessary to have the support of human resources who have quality in accordance with educational qualifications in their fields, so that in carrying out the duties and functions of employees can run well and professionally, especially in the face of demands Public services that are getting better and of higher quality are needed, otherwise it will not be optimal for the community. This means that civil servants to realize professional implementation of work in serving the community (public), the government must continue to maintain the program to improve the quality of human resources (civil servants) as has been done so far; even if the volume and material delivered in education and training must be increased, innovation must be carried out (Muchdarsyah 2002) [19]. Regional Civil Service Agency employees are expected to improve their professionalism by continuing their education to a higher level. This is also evidenced by the number of employees who continue their education to the Strata 3, Strata 2 and Strata 1 levels.

Based on the discussion above, several findings can be obtained:

Finding 10 : The implementation of the duties and functions of employees can run well and professionally, especially in facing the demands of public services

Finding 11 : In order to be professional in providing services to the public, employees are provided with education and training

Finding 12 : The professional attitude of employees at the Regional Personnel Agency of East Kutai Regency is shown by the reliability of employees in carrying out their duties so that they are carried out with high quality, at the right time, carefully, and with procedures that are easy to understand and follow by those who need services.

From the findings regarding the Behavior of the Regional Personnel Agency of East Kutai Regency seen from employee professionalism obtained:

Proposition 4 : On Employment Agency The implementation of employee duties and functions can run well and professionally, especially in facing the demands of public services with the provision of education and training on employee reliability in carrying out their duties so that they are carried out with high quality, right time, carefully, and with procedures that are easy to understand and follow. by those in need of services.

\subsubsection{Skills}

Employee skills, including improving the quality of employee resources, are very urgent and need to be carried out in a planned, directed, and sustainable manner in order to improve abilities and professionalism. The target of developing the quality of employee resources is to improve the operational performance of employees in carrying out government tasks. In addition, the high quality of employee resources will lead to the birth of a strong commitment in completing routine tasks according to their respective responsibilities and functions more efficiently, effectively, and productively.

The phenomenon of the findings in the field can be explained that the increase inn human resources of the apparatus, one of which is the improvement of skills, both technical skills (hard skills) and skills to manage self and others (soft skills). This is done through improving technical skills and skills to manage self and others. In an effort to improve our technical skills, we have carried out various kinds of education and skills training. The improvement of technical skills (hardskills) is carried out by sending employees to participate in technical training programs carried out at the provincial and central levels, in addition to those carried out in their own regions.

Related to the skill of an employeei at the Regional Personnel Agency of East Kutai Regency, it was found that the Skills possessed by ASN in the Regional Personnel Agency of East Kutai Regency are the ability to carry out a certain task both physically and mentally, this is of course influenced by in carrying out a series of tasks required. impact on their experience in completing a job. In my opinion, the average employees here are employees who have worked in their field for a long time so that their ability is no doubt in completing their work.

Based on the discussion above, several findings can be obtained:

Finding 13 : Improvement of human resources of the apparatus, one of which is the improvement of skills, both technical skills (hard skills) and skills to manage self and others (soft skills). 
Finding 14 : The skills possessed by ASN at the Regional Personnel Agency of East Kutai Regency are the ability to carry out a certain task, both physically and mentally.

Finding 15 : We can see the skills of the Regional Personnel Agency of East Kutai Regency in completing the work

From the findings regarding the Behavior of the Regional Personnel Agency of East Kutai Regency seen from employee skills obtained:

Proposition 5 : Enhancementn skills, both technical skills (hard skills) and self-management skills (soft skills) possessed by ASN in the Regional Personnel Agency of East Kutai Regency is the ability to carry out a certain task, both physically and mentally

\subsubsection{Attitude}

In the study it was found that in the BKD of East Kutai Regency, in order to improve the attitude, attitude and behavior of employees. The East Kutai Regional Personnel Agency has several times carried out activities whose main purpose is to improve attitudes, attitudes and behavior, including ESQ (Emotional Spiritual Quotient) training, outbound activities, heart management training, and post-service training for prospective retired employees.

Attitude of employees at employeeIn the Regional Personnel Agency, it can be said that it is very supportive in the duties of an employee in carrying out his work. The attitude of employees at the Regional Personnel Board of East Kutai Regency cannot be separated from any behavior, attitude or action taken by civil servants or not doing something that should be done in accordance with the provisions of the law. If the regulations are clear that regulate employee ethics as stated in Government Regulation No. 42 of 2004 concerning the Guidance of Corps Spirit and the Code of Ethics for Civil Servants. Its implementation has also been applied to the service sector, employees have a good attitude in providing services, in terms of commitment, civil servants here also have the will and ability to harmonize attitudes and actions to realize organizational goals.

In other words, attitude as part of competence is mastery of a set of knowledge, skills, values and attitudes that lead to performance and are reflected in the habit of thinking and acting in accordance with their profession. Thus, competence shows skills or knowledge characterized by professionalism in a particular field as the most important. Competence as a person's characteristics related to effective performance in a job or situation.

Based on the discussion above, several findings can be obtained:

Finding 16 : Efforts to improve the attitude or behavior of employees within the Regional Personnel Agency are carried out in various ways and in various ways, including the implementation of morning apples which are held every morning.

Finding 17 : Activities whose main purpose is to improve attitudes, attitudes and behavior include ESQ (Emotional Spiritual Quotient) training, outbound activities, heart management training, and post-service training for prospective retired employees.

Finding 18 : The attitude of employees to employees within the Regional Personnel Agency can be said to be very supportive in the duties of an employee in carrying out his work.

From the findings regarding the Behavior of the Regional Personnel Agency of East Kutai Regency seen from employee attitude obtained:

Proposition 6 : Efforta to improve the attitude or behavior of employees within the Regional Civil Service Agency in the form of activities whose main purpose is to improve attitudes, attitudes and behavior can be said to be very supportive in the duties of an employee in carrying out his work.

\subsubsection{Responsibilities}

The responsibilities of employees in a government institution include responsibilities at work, leaders/supervisors, companies, and the community. Phenomenon in the fieldshowat the Regional Personnel Board of East Kutai Regency at all times given motivation and enthusiasm so that these employees can complete their duties and functions as stated in the job descriptions and functions of positions and responsibilities. This is in line with what was stated (Handoko, 2003:171) which states that responsibility is a consequence of an authority possessed by an employee [20]. Authority is the right to do something or to order others to do or not to do something in order to achieve certain goals. From the authority they have, to take or not to take an action, 
employees must be willing to accept the logical consequences of their actions. This logical consequence is often referred to as responsibility.

The results of the study also found that the application of the attitude of responsibility of a civil servant in the Regional Personnel Agency of East Kutai Regency cannot be separated from our role as Civil Servants (PNS) who are State Servants who have duties and responsibilities in carrying out service duties in accordance with their fields and expertise. in the context of implementation and supervision based on competence and performance. The responsibilities of a civil servant are also the obligations of civil servants as regulated in the provisions of Articles 4.5 and 6 of Law Number 43 of 1999 concerning the Principles of Employment. Article 5 states that every civil servant is obliged to obey all applicable laws and regulations and carry out the official duties entrusted to him with full dedication, awareness and responsibility.

The results of the study indicate that in the Regional Personnel Agency of East Kutai Regency, the implementation of employee responsibilities cannot be separated from discipline problems, seen from the implementation of tasks that are in accordance with their principals and functions and the division of labor seen from superiors is evenly distributed and pays attention to the abilities of their subordinates.

Responsibility is the obligation to perform all duties assigned to employees as a result of the authority received or possessed. Responsibility arises because of the relationship between superiors and subordinates, where superiors delegate their work authority to subordinates to do. Responsibility flows from the bottom up, so it's a backflow of the commandments.

Based on the discussion above, several findings can be obtained:

Finding 19 : At the Regional Personnel Board of East Kutai Regency, motivation and enthusiasm are given at all times so that these employees can complete their duties and functions as stated in the job descriptions and functions of positions and responsibilities.

Finding 20 : In the area of the Regional Personnel Agency of East Kutai Regency, the implementation of employee responsibilities cannot be separated from disciplinary problems

Finding 21 : The application of the attitude of responsibility of a civil servant in the Regional Personnel Agency of East Kutai Regency cannot be separated from the role of a Civil Servant in carrying out service tasks in accordance with their fields and expertise in the context of competency and performance-based implementation and supervision.

From the findings regarding the Behavior of the Regional Personnel Agency of East Kutai Regency seen from employee responsibilities obtained:

Proposition 7 : Employees of the Regional Personnel Board of East Kutai Regency are given motivation and enthusiasm at all times so that they are disciplined in completing their duties and functions as stated in the description of the duties and functions of positions and responsibilities

\subsection{Factor-Factors Behind the Behavior of the Regional Personnel Agency of East Kutai Regency}

\subsubsection{Recruitment or Selection Process for Employees}

The results showed that at the Regional Personnel Agency Office of East Kutai Regency, recruitment was serious because it would have an impact in the future in having an impact on the institution occupied by the employee. In order to prepare employees with the expected work behavior, the recruitment process is carried out through several stages which will select each of the prospective civil servants. Starting from the administrative selection, where data from each prospective civil servant must be complete and accurate which shows that each applicant has clear status and data. Furthermore, competency selection consists of basic competency selection (SKD) and field competency selection (SKB). Selection of basic abilities (SKD) consists of several materials, namely: personal characteristics test, general intelligence test, and national insight test.

The results of the interview also show that the recruitment carried out by the Regional Personnel Agency has undergone changes in both the method and the questions presented. This is done to improve the quality of prospective employees who apply. This recruitment is very instrumental in improving employee performance. Because in the recruitment, there are 3 selections that must be passed by the participants in order to be able to pass and be declared a CPNS. Furthermore, the CPNS is given basic training for 2 weeks and will enter the pre-service stage. In addition, the CPNS is given an explanation of the main duties and functions of the position or position occupied.

One of the follow-ups to the first management function is manpower procurement. Where this is very important in order to get good employees and have a high commitment to the tasks and functions within the organization. Good employees who meet 
qualification standards can only be obtained through effective recruitment efforts, thus the recruitment process must be carefully planned so that there are no mistakes in the recruitment process.

Based on the discussion above, several findings can be obtained:

Finding 22 : The employee recruitment process is carried out in several stages, namely through direct appointments, namely whitening honorary categories one and category two, the second through computer answer sheets, and the third computer assisted test (CAT) system.

Finding 23 : Recruitment is serious because it will have an impact in the future in having an impact on the institution occupied by the employee.

Finding 24 : The recruitment carried out by the Regional Personnel Agency has undergone changes both in the method and the questions presented

From the findings regarding the Behavior of the Regional Personnel Agency of East Kutai Regency seen Recruitment process or selection of employee acceptance obtained:

Proposition 8 : The employee recruitment process is carried out through direct appointments, through computer answer sheets, and thirdly the computer assisted test (CAT) system with methods and questions that have undergone changes, is carried out seriously because it will have an impact in the future in having an impact on the institutions occupied by employees.

\subsubsection{Education}

An organization with any sophisticated technology will not be optimal without adequate employees, so that a company's performance will depend on the performance of its employees. This is in accordance with Gibson's (1996:70) statement that performance is the desired result of behavior. Individual performance is the basis of organizational performance [21]. Organizational performance cannot be separated from the performance of individuals in the organization.

Robbins and Judge (2008:57) suggest that ability is an employee's capacity to perform various tasks in a job [22]. Furthermore, Gibson in Swasto (2003:35) states that the ability shows the potential of an employee to perform various tasks and jobs. Ability is closely related to the physical and intellectual abilities that people have to carry out work [23].

From research in the field, it was found that levelThe knowledge of employees of the East Kutai Regional Personnel Board is still dominated by employees who have a high school education level, followed by undergraduate and postgraduate levels. So that the mindset of employees in the East Kutai Regional Personnel Agency is largely determined by the level of education.

Findings regarding Education to support the behavior and competence of employees at the BKD of East Kutai Regency found that education is part of a performance improvement program that can be pursued through the implementation of formal and non-formal education in the form of training, this concerns the ASN performance and behavior improvement program has been carried out and implemented in accordance with the laws and regulations and the regent's regulations which are the legal basis for the existing .

The results also show that technically, formal education and education and training (education and training) in the Personnel Agency of East Kutai Regency as a means to improve work behavior that affects employee performance or HR are basically inspired by ideas related to Good Governance. Education for employees is a follow-up to realizing good governance, one of which is by increasing the competence of employees implementing public services or the bureaucracy as an effort to increase the effectiveness of public services which in the end good governance is expected to be achieved.

Based on the discussion above, several findings can be obtained:

Finding 25 : The education level of employees of the East Kutai Regional Personnel Board affects the mindset of employees

Finding 26 : Education is part of a performance improvement program that can be pursued through the implementation of formal and non-formal education in the form of training in the context of improving the performance and behavior of ASN

Finding 27 : Formal education and education and training (education and training) that exist in the Personnel Agency of East Kutai Regency as a means to improve work behavior that impact on employee performance or HR are basically inspired by ideas related to Good Governance. 
From the findings regarding the Behavior of the Regional Personnel Agency of East Kutai Regency seen Employee education obtained:

Proposition 9 : The education level of employees of the East Kutai Regional Personnel Agency influences the mindset of employees which can be improved through the implementation of formal and non-formal education in the form of training as a means to improve work behavior and employee performance.

\subsubsection{Knowledge}

One of the factors that influence employee work behavior is the knowledge possessed by employees who are more oriented towards intelligence and thinking power as well as broad knowledge mastery possessed by employees, with employee knowledge formed from a number of competencies possessed by an employee which includes high education, discipline , cooperation and responsibility for the quality of work resulting from experience by a combination of the ability and willingness of an employee who has the ability and willingness to produce good quality. However, if one of the two factors is not present, even if both are absent, then the quality of work is low, ability can be increased by recruiting people who are already capable or training existing employees.

Every employee must have a strong desire and job satisfaction to be able to develop and have adequate knowledge, ability, and loyalty in order to achieve employee performance and career advancement that will directly advance the company. hinder the tasks assigned by the company. With this knowledge of employee development, it can affect work performance, thereby improving the performance and quality of work of the employee concerned, which in the end will be able to achieve the goals that have been previously set on time. Knowledge reflects the cognitive abilities of an employee in the form of the ability to understand, understand, and live up to a task or job. An employee's knowledge can be developed through education, both formal and non-formal as well as experience. Education equips a person with the basics of knowledge, theory, logic, general knowledge, analytical skills as well as character and personality development.

The results of the research in the field found that the knowledge of an employee is part of supporting employee competence, an employee must have knowledge of every task or job he carries out, an employee at BKD for example in completing his work he must know how to identify what must be done first and how do a good job in accordance with the existing needs effectively and efficiently in the BKD organization.

The results of research in the field also found that employee knowledge was influenced by the type of educational qualification where in practice there were still many that were not in accordance with the existing position. Employees who meet the educational/knowledge qualification requirements have relatively high self-confidence and the ability to complete job duties well.

Based on the discussion above, several findings can be obtained:

Finding 28 : This knowledge of an employee is part of supporting employee competence

Finding 29 : Employees who meet the educational/knowledge qualification requirements have relatively high selfconfidence and the ability to complete job duties well.

Finding 30 : Employee knowledge is influenced by the type of educational qualification where in practice there are still many that are not in accordance with the existing position.

From the findings regarding the Behavior of the Regional Personnel Agency of East Kutai Regency seen Employee knowledge obtained:

Proposition 10 : This knowledge of an employee is part of supporting employee competence in completing job duties well but in practice there are still many that are not in accordance with the existing position.

\subsubsection{Income}

Every employee in an agency has its own interests and goals when the employee joins the company agencyand it cannot be denied that the goal for most people, especially employees in an agency, is to earn a living and earn money. This means that if an employee has done a good performance, the employee will expect rewards both in money and in other forms. Ideally every agency should be able to balance the achievement of the goals of its employees. 
HaThe results of the study show that employees at the East Kutai Regional Personnel Agency will be motivated to work diligently if their salaries are paid on time, especially if their salaries are increased. Because the amount of salary not only affects our behavior at work but also greatly affects behavior in the family.

The policy of providing additional income for state civil servants is very important to note, because this is related to the work results of employees in carrying out their work. By providing additional income for state civil servants in accordance with predetermined work standards, it means giving satisfaction and making a stronger relationship between employees and the institution where they work. received, if the employee does not get additional income for the civil servant employee in accordance with the amount of sacrifice in work, then these employees tend to be lazy to work and not enthusiastic and finally they work as they please without adequate job satisfaction, which is as expected by the employee. Therefore, the relationship that leads to the achievement of goals will produce very beneficial results for both the agency and the employees themselves.

The results of the study also show that the BKD employees of East Kutai Regency since the implementation of the provision of TPP which of course has an impact on employee income, there is an increase in employee behavior or competence. Before the implementation of the TPP, BKD employees in particular worked not with enthusiasm, they were always sluggish. But since the existence of the TPP, at least employees can be happy at work.

The main purpose of providing additional income to employees is basically to motivate them to work better and be able to show good performance. additional income for employee performance is one of the important things to provide enthusiasm in doing everything related to the wishes and needs of the agency. This method is a very effective way to improve employee performance and motivate employees to work.

Based on the discussion above, several findings can be obtained:

Finding 31 : Employees at the East Kutai Regional Personnel Agency will be motivated to work diligently if their salaries are paid on time, especially if their salaries are increased.

Finding 32 : Employee income has a positive influence on increasing employee competence or performance in times of increasing demand and prices.

Finding 33 : The enactment of the provision of TPP which of course has an impact on employee income, there is an increase in employee behavior or competence

From the findings regarding the Behavior of the Regional Personnel Agency of East Kutai Regency seen Employee Income obtained:

Proposition 11 : Employees at the East Kutai Regional Personnel Agency will be motivated to work diligently if the salaryi is paid on time especially if their salary is increased in times of need and prices are increasing and impacting on employee income there is an increase in employee behavior or competence

\subsubsection{Lifestyle}

The current lifestyle of civil servants has followed the lifestyle of developed countries, a hedonic lifestyle causes people to behave consumptively, this consumptive lifestyle is also supported by the growing development of recreation areas, culinary tours and shopping places that are mushrooming in the surrounding environment, employees must fortify so as not to be carried away by the environment that leads to patterns of consumptive behavior.

The phenomenon of consumptive behavior for civil servants can be said to be everything that is instantaneous, not appreciating a process before a certain achievement occurs and also not being accompanied by good financial planning, it will trigger consumptive behavior that can harm yourself in the future.

The results of the study show The lifestyle of employees of course has something to do with employee behavior, if the employee is able to adjust his daily lifestyle with the income he earns, of course this will not have an impact on their work behavior, but on the contrary if they are more consumptive, of course, their income will not be able to cover it. The employee is trapped in wrong thoughts about an instant modern lifestyle and tends to be luxurious and also causes other deviations such as the case of workers who are not focused on work and this has happened a lot in office workers and civil servants lately.

The consumptive lifestyle of civil servants more specifically explains the desire to consume goods that are actually less needed in excess to achieve maximum satisfaction (Tambunan, 2001: 1). According to Aprilia \& Hartoyo (2013: 73) consumptive behavior is individual behavior that is influenced by sociological factors in their lives which are shown to consume excessively or wastefully and unplanned towards services and goods that are less or even not needed [24].

Based on the discussion above, several findings can be obtained: 
Finding 34 : The lifestyle of employees is related to employee behavior so that employees must be able to adjust their daily life patterns with the income earned

Finding 35 : To fulfill their lifestyle, sometimes civil servants take credit from banks beyond their ability

Finding 36 : The impact of taking credit at the bank is beyond the employee's ability limit, resulting in employees no longer focusing on work which is their duty and responsibility

From the findings regarding the Behavior of the Regional Personnel Agency of East Kutai Regency seen Employee Lifestyle obtained:

Proposition 12 : The employee's lifestyle is related to employee behavior so that employees must be able to adjust their daily life patterns with the income earned and not take credit from banks beyond the employee's ability limit, resulting in employees no longer focusing on work which is their duty and responsibility.

\subsubsection{Environment}

The organization as the parent company must provide a comfortable and conducive work environment that is able to provoke employees to work productively. Providing a comfortable work environment will be able to provide satisfaction to employees for the work done and give a deep impression to employees which in the end employees will have good performance. Research on the work environment conducted by Strek (2005) in the book Management of Modern Office Administration by Badri (2006: 207), explains that employees expect a comfortable work environment that can pamper employees at work. Then research conducted by Chao, Schwartz, Milton and Burge (Badri, 2006: 207),

The results of the study show sthatThe environment of the East Kutai Regency BKD office which is still borrowing the Bappeda building makes the working atmosphere not optimal. This shows that the work environment is one of the important factors in creating employee work behavior because the work environment has a direct influence on employees in completing work which will ultimately improve organizational performance. The environment is a place where employees do their daily work. A conducive work environment provides a sense of security and allows employees to work optimally. The work environment can affect the emotions of employees. If the employee likes the work environment in which he works,

The results also show that The environment is very influential in shaping the work behavior of BKD employees, although this is not a building belonging to the organization, but a good working atmosphere is created and the relationship between employees is also good, also supported by adequate work facilities.

A work environment that is a work atmosphere or conditions that exist around employees who are doing work that can affect the implementation of the work itself. This work atmosphere will include the workplace, facilities and tools for cleaning work, lighting, tranquility including the working relationship between the relationships between the people in the place.

Based on the discussion above, several findings can be obtained:

Finding 37 : The environmental situation of the East Kutai Regency BKD Office which is still borrowing the Bappeda building makes the working atmosphere not optimal

Finding 38 : The environment is very influential in shaping the work behavior of BKD employees

Finding 39 : At the BKD Office, East Kutai Regency, a good working atmosphere is created and the relationship between employees is also good, also supported by adequate work facilities.

From the findings regarding the Behavior of the Regional Personnel Agency of East Kutai Regency seen Employee Environment obtained:

Proposition 13 : The environmental situation of the BKD Office in East Kutai Regency has an influence in shaping the work behavior of BKD employees, although they still borrow the Bappeda building, making the work atmosphere not optimal, but a good working atmosphere is created and the relationship between employees is also good, also supported by adequate work facilities.

Its Major Propositions are as follows:

Major Proposition : Employee behavior at the Regional Personnel Board of East Kutai Regency as a manifestation of Employee Competency Standards with an emphasis on employee order and discipline, work spirit/employee work ethic, Cooperation, Professionalism, Skill, Attitude, and Responsibilities of 
employees supported by a recruitment or selection process for employee recruitment, Education, Knowledge, Income, Lifestyle and employee work environment.

\section{CLOSING}

\subsection{Conclusion}

1) The behavior of the Regional Personnel Agency of East Kutai Regency according to the results of the study can be concluded as follows:

a. Order and discipline of employees at BKD East Kutai Regency is an example for other agencies, offices or work units carried out with full awareness and implementation is part of the organizational culture

b. Increasing employee morale and work ethic is carried out by providing motivation As a result of the increasing public demand for public services

c. At the Civil Service Agency, cooperation is a necessity to realize success in providing public services where with a teamwork system employees will be helped and feel the benefits compared to working alone.

d. At the Employment Agency, the implementation of employee duties and functions can run well and professionally, especially in facing the demands of public services with the provision of education and training on employee reliability in carrying out tasks so that they are carried out with high quality, right time, carefully, and with procedures that are easy to understand and followed by those who need services.

e. Psayn skills, both technical skills (hard skills) and self-management skills (soft skills) possessed by ASN in the Regional Personnel Agency of East Kutai Regency is the ability to carry out a certain task, both physically and mentally

f. Efforta. to improve the attitude or behavior of employees within the Regional Personnel Agency, it is carried out in the form of activities whose main purpose is to improve attitudes, attitudes and behavior, which can be said to be very supportive in the duties of an employee in carrying out his work.

g. Employees of the Regional Personnel Board of East Kutai Regency are given motivation and enthusiasm at all times so that they are disciplined in completing their duties and functions as stated in the description of the duties and functions of positions and responsibilities.

2. Factors Behind the Behavior of employee of the Regional Personnel Agency of East Kutai Regency

a. The employee recruitment process is carried out through direct appointments, through computer answer sheets, and thirdly the computer assisted test (CAT) system with methods and questions that have undergone changes, is carried out seriously because it will have an impact in the future in giving impact to the institutions occupied by employees.

b. The education level of employees of the East Kutai Regional Personnel Agency influences the mindset of employees which can be improved through the implementation of formal and non-formal education in the form of training as a means to improve work behavior and employee performance.

c. This knowledge of an employee is part of supporting employee competence in completing job duties well but in practice there are still many that are not in accordance with the existing position.

d. Employees at the East Kutai Regional Personnel Agency will be motivated to work diligently if the salaryi is paid on time especially if their salary is increased in times of need and prices are increasing and impacting on employee income there is an increase in employee behavior or competence

e. The employee's lifestyle is related to employee behavior so that employees must be able to adjust their daily life patterns with the income earned and not take credit from banks beyond the employee's ability limit, resulting in employees no longer focusing on work which is their duty and responsibility.

f. The environmental situation of the BKD Office in East Kutai Regency has an influence in shaping the work behavior of BKD employees, although they still borrow the Bappeda building, making the work atmosphere not optimal, but a good working atmosphere is created and the relationship between employees is also good, also supported by adequate work facilities. 


\subsection{Implications of Research Results}

1) Theoretical Implications

Research conducted on PeThe behavior of employees at the Regional Personnel Agency of East Kutai Regency (Study of Social Reality on Employee Competency Standards) has supported McClelland's theory in Sedarmayanti (2012:61), which is "competence is a fundamental characteristic possessed by a person that has a direct influence on, or can predict excellent performance". In other words, competence is what outstanding performers do more often, in more situations, with better results, than what policy raters do. McClelland provides an overview that facilitates the understanding of these competencies. Competence is put forward as a concept of a combination of skills which in this case is in the form of Professionalism and Skill,

2) Practical Implications

PeEmployee behavior at the Regional Personnel Board of East Kutai Regency as an effort to increase competence through the implementation of Perka BKN No. 7 of 2013 concerning Managerial Competency Standards and Perka BKN No. 8 of 2013 concerning Technical Competency Standards in order to improve employee performance has considered employee behavior seen from employee order and discipline, employee work spirit / work ethic, Cooperation, Professionalism, Skill, Attitude, and Responsibilities of employees supported by a recruitment or selection process employees, Education, Knowledge, Income, Lifestyle and employee work environment.

\subsection{Suggestions}

1) Theoretical Suggestions

Further research should be carried out by developing the perspective of PeEmployee behavior at the Regency Regional Personnel Boardand it is recommended that researchers can carry out direct observations on each mission implementation activity at the research location, to be able to see clearly broader employee behavior in various forms of cases and varied settings.

2) Practical Advice

Should be done changes that are not interpreted in total, but are gradually related to the problem of the lack of a work environment that is still not owned so that the behavior of employees at the Regional Personnel Board of Kutai Regency can achieve what is expected.

\section{REFERENCES}

1. Hall, Richard D. and Robert E. Quinn, 1998. Organizational Theory and Public Policy, Sage Publications, London.

2. Hasibuan, Malay. 2000. Human Resource Management. Edition. Revisi. Jakarta: PT Bumi 2. Aksara.

3. Ibrahim, Rusli 2001, Social Behavior Development. Jakarta: Ditjen Dikdasmen, Ministry of National Education.

4. Malinowski, Bronislaw. 1997, The Symbolic Construction of Community. Routledge: New York.

5. Mills, Edward D. 1976. Planning Building for Administration, Entertainment and Recreation. New York: Robert E. Krieger Publishing Company.

6. Hasibuan S.P. Malayu, 1995. Human Resource Management, Jakarta, Gunung. Great,

7. Dessler, G. 2000. Human Resource Management. 8th edition. New Jersey: Prentice-Hall,. Inc.

8. Lefrancois, Guy R., 1995, Theories of Human Learning. Kro: Kros Report.

9. Berger, Peter L. 1991. Sacred Heaven; Religion as a Social Reality, Jakarta: LP3ES.

10. Basrowi and Sukidin, Micro Perspective Research Methods: Grounded theory, Phenomenology, Ethnomethodology, Ethnography, Dramaturgy, Symbolic Interaction, Hermeneutics, Social Construction, Discourse Analysis, and Reflection Methodology, Surabaya: Insan Gendekia, 2002.

11. Mulyana, Deddy, 2003. Qualitative Research Methodology: A New Paradigm of Communication and Other Social Sciences, Bandung: PT Remaja Rosdakarya, 2003.

12. Soekanto, Soerjono. 1988. Sociological Approach to Law, Jakarta: Bina Aksara, 1988.

13. Miles, M.B, Huberman, A. M, and Saldana, J. 2014. Qualitative Data Analysis, A. Methods Sourcebook Edition 3. 
14. Wathon, Nasrul et al. 2005. The Influence of Individual Factors, Organizational Culture and Work Behavior on Employee Performance at the Yogyakarta Tax Service Office Dua.SinergiSpecial Edition Human Resources p.111-127

15. Robbins, Stephen.P, 2002. Organizational Behavior, Prenhallindo, Jakarta.

16. Robbins, P. Stephen. 2006. Organizational Behavior. Edition Ten. Translated by: Drs. Benjamin Molan. Erlangga, Jakarta.

17. Pandelaki, M. T. 2018. The Influence of Teamwork and Work Culture on the Performance of Titian Budi Luhur Foundation Employees in Parigi Moutong Regency. Journal of Postgraduate Management Masters at Tadulako University Palu Vol. 6, No. 5, 35-46.

18. Bachtiar, 2004. Human Resource Management. Iteraksa, Batam.

19. Muchdarsyah, Sinungan. 2003. Productivity What and How. Bandung: Earth Literacy.

20. Handoko, T. Hani. 2003. Management Edition 2. BPFE. Yogyakarta.

21. Gibson, Ivancevich, Donnely, 1996. Organization and Management, Behavioral Structure. Process, Erlangga, Jakarta.

22. Robbins, Stephen P. and Timothy A. Judge. 2008. Organizational Behavior 12th Edition,. Jakarta: Salemba Empat.

23. Swasto, Bambang. 2003. Human Resource Development (Influence on Performance and Rewards). Malang: Bayumedia.

24. Aprilia, D., \& Hartoyo. 2013. Sociological Analysis of Student Consumptive Behavior (Study on FISIP Students, University of Lampung). Journal of Sociology 72-86. 